Anna Strojna-Krzystanek

(Politechnika Krakowska)* $^{*}$

\title{
MARIA HUELLE - PIERWSZA STUDENTKA NA POLITECHNICE LWOWSKIEJ
}

\begin{abstract}
Streszczenie. W polskiej literaturze przedmiotu dotyczącej historii oświaty niewiele jest źródeł, na podstawie których w pełni możemy odtworzyć okoliczności, w jakich kobiety zaczęły studiować na uczelniach technicznych. Źródła znajdujące się poza granicami Polski dodatkowo utrudniają kompletne opracowanie tego zagadnienia. W poniższym artykule autorka przybliża postać oraz biografię Marii Huelle jednej z pierwszych kobiet na Politechnice Lwowskiej. Wpisała się ona w historię tej uczelni jako jedna z pierwszych studentek i asystentek.
\end{abstract}

Słowa kluczowe: Politechnika Lwowska, dwudziestolecie międzywojenne, historia oświaty, kobiety na uczelniach technicznych, kobiety na Politechnice Lwowskiej.

P

rzełom XIX i XX w. to okres szczególny w rozwoju oświaty, otwierający nowe możliwości zwłaszcza dla kobiet. Zmiany technologiczne i gospodarcze zachodzące w całej Europie spowodowały zwrot w ówczesnym podejściu do roli i miejsca kobiety w życiu społecznym. Kobiety z coraz większą determinacją walczyły o poszerzenie swoich praw oraz o pełen dostęp do edukacji. Wychodząc naprzeciw ich oczekiwaniom, uniwersytety w Szwajcarii, Belgii, Francji i Anglii otwierały swoje drzwi dla studentek. Działania te spowodowały głębokie poruszenie oraz dezaprobatę wśród środowisk konserwatywnych. Mimo ogólnego sprzeciwu społecznego uniwersytety zlokalizowane na terenach objętych zaborami zaczęły wykazywać podobne trendy. Sytuacja zaczęła zmieniać

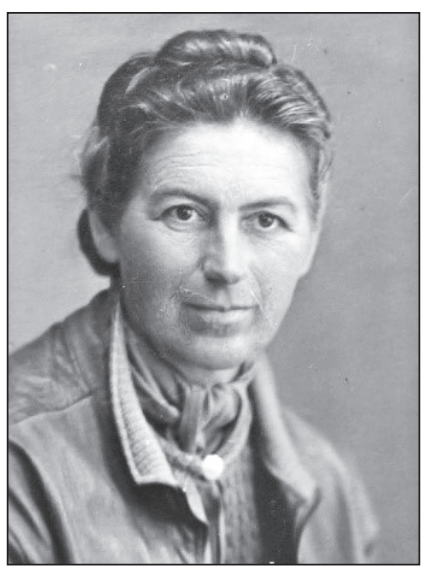

Fot. 1. Maria Huelle (Źródło: Archiwum Grupy Azoty S.A. w Tarnowie) się po odzyskaniu niepodległości i utworzeniu Drugiej Rzeczypospolitej. Kobiety uzyskały wówczas równouprawnienie polityczne, a tym samym większe

*Biblioteka Politechniki Krakowskiej, e-mail: strojna@biblos.pk.edu.pl. 
możliwości podejmowania studiów. Do dziś dnia zachowało się sporo źródeł, na podstawie których można odtworzyć listy studentów. Dzięki tym dokumentom można zauważyć, że ówczesne studentki miały dość łatwy dostęp do uniwersytetów, z kolei uczęszczanie na studia politechniczne było mocno utrudnione.

Politechnika Lwowska była wiodącą uczelnią w dwudziestoleciu międzywojennym. Niestety, po II wojnie światowej znalazła się poza granicami Polski, efektem czego był ograniczony, a z czasem wręcz niemożliwy dostęp do jej archiwów.

Maria Huelle jest sztandarowym przykładem kobiety tamtych czasów. Autorce tekstu udało się dotrzeć do osób, które osobiście znały panią Marię, podzieliły się wspomnieniami o niej oraz udostępniły prywatne zbiory dotyczące bohaterki ${ }^{1}$.

Maria Huelle z domu Fiedler urodziła się 1896 r. we Lwowie². W tym mieście spędziła dzieciństwo, tam również pobierała nauki w miejscowych szkołach. Jako absolwentka szkoły powszechnej oraz gimnazjum klasycznego im. Juliusza Słowackiego w 1914 r. zdała maturę z wyróżnieniem. Maria planowała kontynuowanie nauki, niestety zamierzenia te pokrzyżował jej wybuch I wojny światowej. Pierwsze miesiące wojennej zawieruchy spędziła wraz z rodziną w Szwajcarii, lecz gdy tylko sytuacja ustabilizowała się, powróciła do Lwowa.

W 1915 r. Maria została studentką Wydziału Filozoficznego Uniwersytetu Franciszkańskiego we Lwowie, gdzie studiowała trzy i pół roku, mimo iż chciała studiować w lwowskiej Szkole Politechnicznej. Od roku 1911 do 1918 kobiety mogły uczyć się w tej uczelni jedynie w charakterze wolnych słuchaczek, co oznaczało, że brały udział $\mathrm{w}$ zajęciach w szkole wyższej, ale nie posiadały uprawnień studenta. Odzyskanie niepodległości przez Polskę w 1918 r. zmieniło podejście kadry uczelni do kształcenia kobiet i Maria skorzystała z tej reformy. Dostała pozwolenie od władz uczelni na studiowanie w charakterze studentki zwyczajnej, zostając jedną z pierwszych studentek Politechniki Lwowskiej i kontynuując naukę w tej Alma Mater.

Powodem jej determinacji w dążeniu do nauki był niewątpliwie wpływ ojca Tadeusza Fiedlera ${ }^{3}$, dwukrotnie rektora Szkoły Politechnicznej we Lwowie, jak również profesorów tamtejszych uczelni wyższych, którzy byli również jej nauczycielami w gimnazjach. To oni zafascynowali ją nauką i jej bezkresem.

${ }^{1}$ Autorka składa serdeczne podziękowania Pani Barbarze Bułdys oraz Panu Zygmuntowi Szymanowskiemu za podzielenie się swoimi wspomnieniami i wiedzą o historii powstawania Mościc.

${ }^{2}$ Informacje biograficzne pochodzą z Teczki osobowej Marii Huelle przechowywanej w Archiwum akt osobowych Zakładu Grupy Azoty w Tarnowie.

${ }^{3}$ Poczet energetyków polskich. Prof. inż. Tadeusz Fiedler. Profesor honorowy i doktor honoris causa Politechniki Lwowskiej. Członek rzeczywisty Akademii Nauk Technicznych w Warszawie (1858-1933), s. 7-9 [http://elektroenergetyka.pl/upload/file/2005/1/elektroenergetyka_nr_05_01_2.pdf - dostęp: 18.12.2018]. 


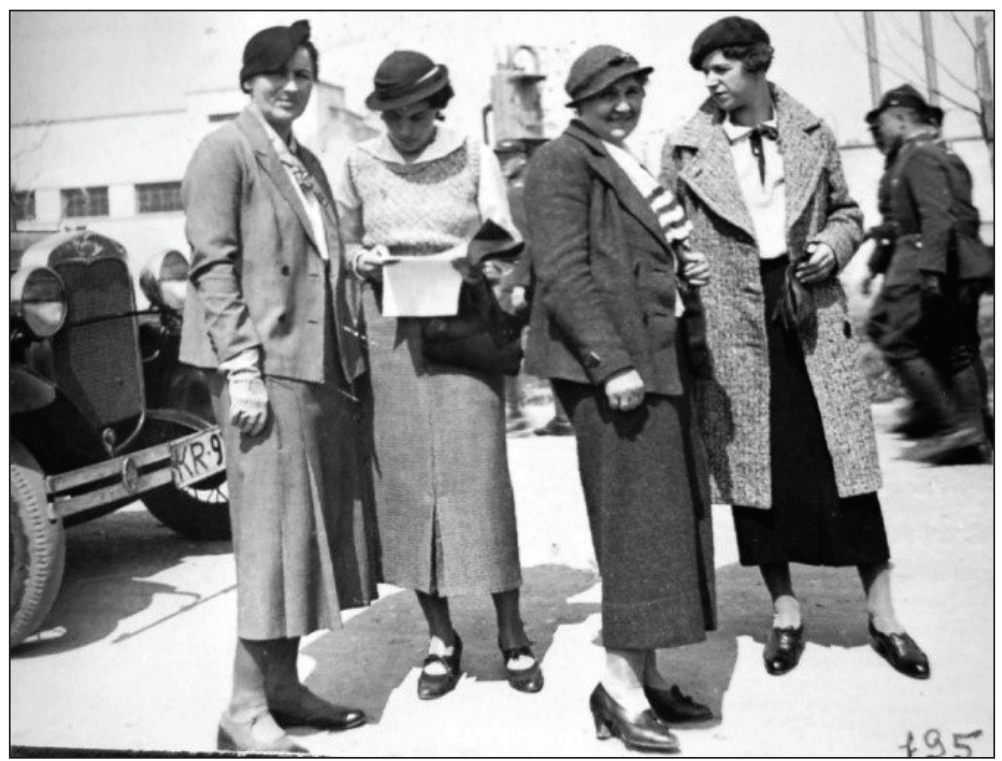

Fot. 2. Od lewej strony: P. Hüelle, P. Łachecka, P. Wojnarska, P. Kubińska (Źródło: archiwum prywatne Zygmunta Szymanowskiego)

Jako osoba nieprzeciętna zarówno pod względem charakteru, jak i posiadanej wiedzy Maria zwróciła na siebie uwagę profesora Ignacego Mościckiego i na przełomie lub w roku akademickim 1920/21 została jego młodszą asystentką w Katedrze Mykologii Technicznej. W 1921 r. Maria Huelle zakończyła studia z tytułem dyplomowanego inżyniera chemika i do czerwca 1924 r. obejmowała stanowisko starszej asystentki przy Katedrze Technologii Chemicznej Nieograniczonej i Elektrotechniki Technicznej.

Podczas pracy na Politechnice Lwowskiej Maria poznała swojego przyszłego męża, znakomitego chemika i inżyniera Karola Huelle. Po ślubie, który miał miejsce w 1924 r. zrezygnowała z pracy na uczelni, poświęcając się rodzinie. Przez okres kolejnych trzech lat wraz z mężem przeprowadzała się do Jaworzna, Warszawy, aby powtórnie powrócić do Lwowa. Przez 15 kolejnych miesięcy Maria pracowała w Rozlewni Wódek Towarzystwa Gorzelni Rolniczych jako specjalistka chemik i kierowniczka oddziału.

W 1927 r. wraz z mężem przeniosła się na stałe do Mościc. Karol był jednym z założycieli i dyrektorów nowo powstających Zakładów Azotowych. Mościce stały się nowym rozdziałem w życiu Marii. Wraz z inwestycjami związanymi z fabryką rozpoczęła się budowa osiedli mieszkaniowych dla kadry inżynierskiej, nazwanych „dzielnicą ogrodem”. Zamieszkanie w takim miejscu stworzyło wręcz idealne warunki do tego, aby Maria oddała się bez reszty swojej drugiej pasji - ogrodnictwu. 
II wojna światowa to czas niezwykle trudny zarówno dla państwa Huelle, jak i innych rodzin powiązanych z Zakładami Azotowymi w Mościcach. Karol wraz z większością inżynierów został aresztowany oraz wysłany do obozu koncentracyjnego w Auschwitz (20 czerwca 1940 r., nr obozowy 983). Cały trud wychowania dwójki dzieci i budowy domu spadł na barki Marii. Karol przebywał w obozie koncentracyjnym do 13 czerwca 1941 r. ${ }^{4}$ Powodem jego zwolnienia była interwencja Marii oraz żon trójki innych inżynierów u Hansa Franka, pełniącego funkcję Generalnego Gubernatora. Z relacji Zofii Szymanowskiej wynika, że kobiety udały się 23 maja, w dzień urodzin Hansa Franka, do niego na spotkanie. Jako że w ten szczególny dzień gubernator miał w zwyczaju nie odmawiać żadnym prośbom, czterej inżynierowie z Mościc zostali uwolnieni z obozu.

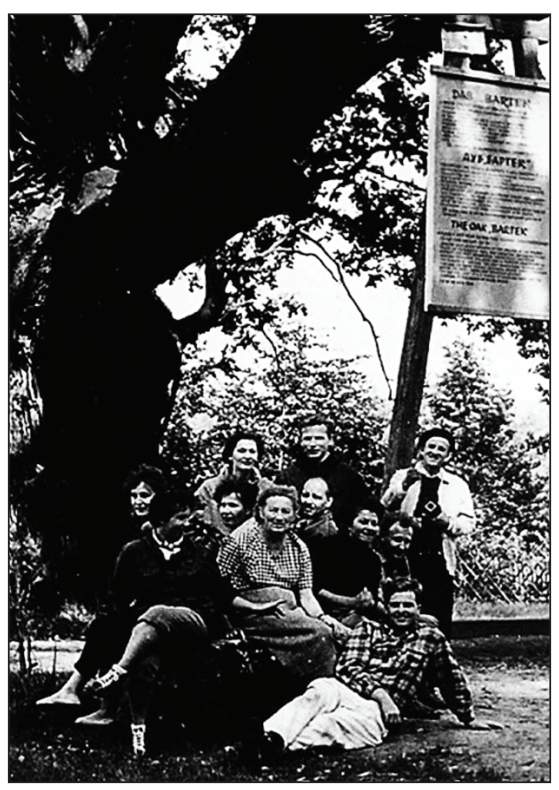

Fot. 3. W środku Maria Huelle (1960 r.). Źródło: A. Krzysztoforski, $W$ moich Zakładach Azotowych, Tarnów 2017.

Po wojnie Karol Huelle został objęty zakazem pracy i mieszkania w Mościcach. Otrzymał pozwolenie jedynie na odwiedziny żony i synów, którzy tam pozostali. Bez perspektyw na pracę $\mathrm{w}$ zawodzie, Karol, podobnie jak wielu przedwojennych inżynierów pracujących w Zakładach Azotowych, udał się na Śląsk. Tam większość z nich zasiliła kadrę naukową w nowo powstającej uczelni wyższej, Politechnice Śląskiej5. Maria, która od blisko 20 lat zajmowała się domem, musiała podjąc pracę zawodową, aby utrzymać rodzinę i dokończyć budowę domu. Pracę rozpoczęła już od września 1945 r., jako nauczycielka w Państwowym Gimnazjum i Liceum Ogólnokształcącym w Mościcach. Ponadto od marca 1946 r. podjęła zatrudnienie w Gimnazjum Mechanicznym Państwowej Fabryki Związków Azotowych w Mościcach, a od września tego roku zaczęła pracę jako referent techniczny w tychże zakładach i pracowała tak do przejścia na emeryturę. Maria Huelle zmarła w roku 1980 i pochowana została na Cmentarzu Komunalnym w Tarnowie.

Maria Huelle - pierwsza studentka Politechniki Lwowskiej - była kobietą, która od najmłodszych lat, aż do ostatnich chwil życia pokazywała, że mimo

${ }^{4}$ Archiwum Państwowego Muzeum Auschwitz-Birkenau w Oświęcimiu, Ankieta Karola Huelle, sygn. Mat/9094, nr inw. 158791.

${ }^{5}$ A. Krzysztoforski, Zakłady Azotowe w Mościcach i Politechnika Śląska w Gliwicach, http://www.chemia.polsl.pl/stowarzyszenie/images/stories/kroniki/2011-12-cz5.pdf, [dostęp: 13.12.2018]. 
niesprzyjającej sytuacji politycznej, kulturowej oraz ciągłych przeciwności losu można realizować swoje plany i marzenia. Jako pierwsza z kobiet zasiadła w ławach Politechniki Lwowskiej, czym stworzyła precedens i utorowała swoim następczyniom drogę w świecie, który przez bardzo długi czas niepodzielnie uważany był za męski. Maria była osobą stanowczą, konsekwentną oraz charyzmatyczną, taką zapamiętał ją wnuk Paweł Huelle, współczesny pisarz gdański, ale to już materiał na inną historię.

\section{BIBLIOGRAFIA}

\section{Źródła:}

Archiwum domowe Zygmunta Szymanowskiego

Zdjęcia Marii Huelle.

Wywiady z Barbarą Bułdys, Zofią i Zygmuntem Szymanowskimi.

Archiwum osobowe Zakładu Grupy Azoty w Tarnowie

Teczka Marii Huelle.

Archiwum Państwowego Muzeum Auschwitz-Birkenau w Oświęcimiu

Ankieta Karola Huelle, sygn. Mat/9094, nr inw. 158791.

\section{Opracowania:}

Krzysztoforski A., W moich Zakładach Azotowych, Tarnów 2017.

Krzysztoforski A., Zakłady Azotowe w Mościcach i Politechnika Ślaska w Gliwicach, [http://www.chemia.polsl. pl/stowarzyszenie/images/stories/kroniki/2011-12-cz5.pdf].

Poczet energetyków polskich. Prof. inż. Tadeusz Fiedler. Profesor honorowy i doktor honoris causa Politechniki Lwowskiej. Członek rzeczywisty Akademii Nauk Technicznych w Warszawie (1858-1933), s. 7-9 [http://elektroenergetyka.pl/upload/file/2005/1/elektroenergetyka_nr_05_01_2.pdf].

\section{Anna Strojna-Krzystanek}

\section{MARIA HUELLE, THE FIRST WOMEN AT THE LVIV POLYTECHNIC}

IN

Polish literature on the history of education, there are just few sources on the basis of which we can fully recreate the circumstances in which women started studying at technical universities. Sources located outside of Poland make it even more difficult to fully elaborate this issue. In the following article the author describes the figure and history of Maria Huelle, one of the first women at the Lviv Polytechnic. She was one of the first students and assistants in the history of this university.

Keywords: Lviv Polytechnic, interwar period, history of education, women at technical universities, women at Lviv Polytechnic. 